\title{
Contact Urticaria Syndrome from Tofu
}

\author{
Maki Kitakawa ${ }^{1}$, Tokio Nakada ${ }^{2 *}$ \\ ${ }^{1}$ Department of Dermatology, Showa University School of Medicine, Tokyo, Japan \\ ${ }^{2}$ Department of Dermatology, Showa University Fujigaoka Hospital, Yokohama, Japan \\ Email: "tokio@med.showa-u.ac.jp
}

Received 13 January 2016; accepted 12 June 2016; published 15 June 2016

Copyright (C) 2016 by authors and Scientific Research Publishing Inc.

This work is licensed under the Creative Commons Attribution International License (CC BY). http://creativecommons.org/licenses/by/4.0/

\section{(c) (i) Open Access}

\begin{abstract}
A-52-year-old woman ate dinner after preening roses in her garden. Immediately, she developed oralaryngeal malaise and pruritic rash. Nasal obstruction and increase of cutaneous lesions were seen although she took betamethasone, $2 \mathrm{mg}$, orally. Physical examination revealed geographic wheal on trunk and extremities, and no overt mucosal lesions. History demonstrated that she had developed such reactions four times before: three of the four were seen shortly after eating soybean. Tofu was examined by prick-by-prick testing, and prick testing was performed with a petal, a piece of stem and rose leaf, positive and negative control. Positive reactions to tofu (wheal, $5 \times 7$ $\mathrm{mm}$ ) and positive control (wheal $5 \times 5 \mathrm{~mm}$ ) and negative ones to others were noted. Although sensitization to soybean seemed to antedate pollen allergy on the basis of interview, oral allergy syndrome could be complicated because of various pollens-specific IgE. Since soy-bean specific IgE was class 2 , such titer was not an effective predictor of clinical severity. This case should be classified into stage 3 of contact urticaria syndrome (CUS). Since CUS can be fatal, we must be careful in management for such patients.
\end{abstract}

\section{Keywords}

Contact Urticaria Syndrome, Prick Testing, Tofu, Soybean

\section{Introduction}

Tofu is soy milk curdled by some coagulating agents called "nigari”. It is widely used in cooking often instead of meat, and regarded as being good for health. However, soy is an allergen that can cause cellulites and dermatitis around lips [1], and late-onset anaphylaxis [2]. In addition, anaphylaxis to tofu is reported [3].

\section{Case Report}

A-52-year-old woman presented at the Dermatology Department with pruritic lesions in November 2011. Past

\footnotetext{
*Corresponding author.
} 
medical history included asthma infuntum (from 3 to 12 years old), and pollen allergy (from 50 years old). She took lunch after taking care of roses in her garden. Immediately, she developed oralaryngeal malaise and pruritic rash. Nasal obstruction and increase of cutaneous lesions were seen although she took betamethasone, $2 \mathrm{mg}$, orally. When she examined the emergency clinic of Dermatology, physical examination revealed geographic wheal on trunk and extremities, and no overt mucosal lesions. As olopatadine hydrochloride, $10 \mathrm{mg}$ per day could not prevent new rash, she was admitted to identify the cause of those behaviors. History taken after admission demonstrated that she had developed such reactions four times before: three of the four were seen shortly after taking food (Table 1). The white blood cell and eosionophils count were $6900 / \mu 1$ and $610 / \mu 1$. Serum IgE level was $621 \mathrm{IU} / \mathrm{ml}$, and antigens specific IgE were detected not only to soybean but to various pollens (Table 2).

Tofu was examined by prick-by-prick testing. In addition, prick testing was performed with a petal, a piece of stem, and a leaf of rose, positive control (histamine chlorhydrate solution, $10 \mathrm{mg} \cdot \mathrm{ml}^{-1}$ ) and negative control (saline) [4]. Those were applied to the volar aspect of left forearm, and were pierced with Prick-Lancetter (Ewo Care AB, Sweden). After 15 minutes, those were wiped off with soft paper tissue, and reading performed. Positive reactions to tofu (wheal, $5 \times 7 \mathrm{~mm}$ ) and positive control (wheal $5 \times 5 \mathrm{~mm}$ ) (Figure 1), and negative ones to others were noted. All of 10 normal controls were prick-by-prick test-negative to tofu.

Table 1. Episodes of contact urticaria syndrome.

\begin{tabular}{|c|c|c|c|c|}
\hline & Age & Meal contents & Onset & Symptoms \\
\hline 1 & 30 (22 years prior) & $\begin{array}{l}\text { loquat } \\
\text { tofu }\end{array}$ & immediately & oral malaise \\
\hline 2 & 46 (6 years prior) & vegetarian diet & unclear & swelling of face \\
\hline 3 & 51 (5 months prior) & $\begin{array}{l}\text { sichuan style bean curd } \\
\text { (Mapo tofu) }\end{array}$ & 15 minutes after & $\begin{array}{l}\text { respiratory discomfort } \\
\text { nausea } \\
\text { generalized urticaria }\end{array}$ \\
\hline 4 & 51 (4 months prior) & $\begin{array}{c}\text { ginger-flavored slices of grilled pork } \\
\text { stir-fried vegetables } \\
\text { (bean sprouts, pepper, eggplant) }\end{array}$ & 15 minutes after & $\begin{array}{l}\text { respiratory discomfort } \\
\text { nasal obstruction } \\
\text { generalized urticaria }\end{array}$ \\
\hline 5 & 52 (initial visit day) & $\begin{array}{l}\text { fried soba with soybean sprouts } \\
\text { apple pie }\end{array}$ & immediately & $\begin{array}{l}\text { oralaryngeal malaise } \\
\text { nasal obstruction } \\
\text { generalized urticaria }\end{array}$ \\
\hline
\end{tabular}

Table 2. Results of antigen-specific IgE.

\begin{tabular}{ccc}
\hline Antigen-specific IgE & $\mathrm{UA} / \mathrm{ml}$ & class \\
\hline birch & $>100$ & 6 \\
Japanese alder & 97.1 & 5 \\
hazel & 54.6 & 4 \\
beech & 48.8 & 4 \\
oak & 48.9 & 4 \\
peach & 18.50 & 3 \\
apple & 9.45 & 3 \\
pear & 3.54 & 3 \\
peanut & 5.74 & 2 \\
soybean & 1.72 & 0 \\
buckwheat & $<0.34$ & \\
\hline
\end{tabular}




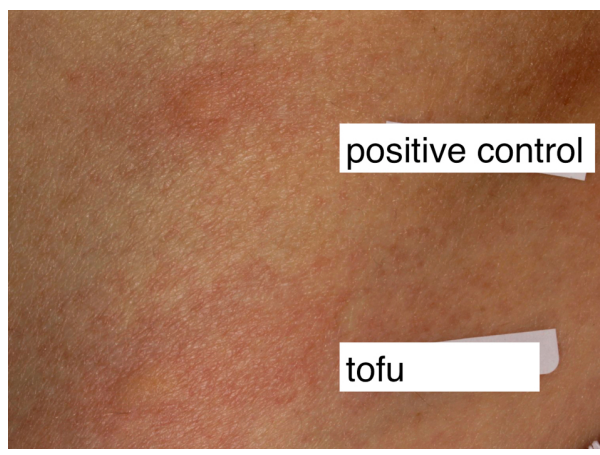

Figure 1. Results of prick-by-prick and prick testing: positive reactions to tofu $(5 \times 7 \mathrm{~mm}$ wheal in diameter) and histamine chlorhydrate solution.

\section{Discussion}

Allergic reactions to soybean embrace various clinical behaviors: contact urticaria syndrome, food-dependent exercise-induced anaphylaxis, and oral allergy syndrome. Classic food allergy is that perioral intake of the same allergen plays a role in sensitization and elicitation. Yagami suggested another type of food allergy: sensitization was established through direct contact to latex or inhalation of allergen-containing particle, and allergic reactions were provoked by not only same allergen but ingestion of vegetables containing the cross-reactive allergens [5]. Such reactions have been called as oral allergy syndrome or latex-fruits syndrome. In this case, although sensitization to soybean seems to antedate pollen allergy on the basis of interview, oral allergy syndrome can be complicated because of various pollens-specific IgE. On the other hand, Lack demonstrated dual-allergen exposure hypothesis for pathogenesis of food allergy: sensitization results from cutaneous exposure and tolerance occurred as a result of oral exposure [6]. It is unclear whether percutaneous or peroral sensitization occurs to soybean in our case. In this case, soybean-specific IgE is class 2 whereas class 5 or 6 to pollens (Table 2). As Sato et al. pointed out, soy-bean specific titer was not an effective predictor of clinical severity [7].

Contact urticaria syndrome (CUS) is classified to 4 stages: from stage 1 (localized urticaria) to stage 4 (anaphylactic symptoms) [8] [9]. This case should be classified into stage 3 of CUS because the patient developed rhinoconjunctivitis and orolaryngeal symptoms as well as generalized urticaria [4] [5]. Since CUS can be fatal, we have to be careful in management for patients with this syndrome.

\section{Acknowledgements}

We gratefully acknowledge the help of Professor Howard I. Maibach, M.D.

\section{References}

[1] Sugiura, K. and Sugiura, M. (2010) Soy Sauce Allergy. Journal of the European Academy of Dermatology and Venereology, 24, 852-855. http://dx.doi.org/10.1111/j.1468-3083.2009.03512.x

[2] Honda, T., Michigami, M., Miyachi, Y. and Kabashima, K. (2014) A Case of Late-Onset Anaphylaxis to Fermented Soybeans (Natto). The Journal of Dermatology, 41, 940-941. http://dx.doi.org/10.1111/1346-8138.12616

[3] Iijima, S., Moriyama, T. and Ogawa, T. (2005) A Case of Anaphylaxis Due to Soy Milk: Trial of Detection of IgEBinding Soybean Proteins. Journal of Environmental Dermatology, 12, 184-191.

[4] Lachapelle, J. and Maibach, H.I. (2012) Methodology of Open (Non-Prick) Testing, Prick Testing, and Its Variants. In: Lachapelle, J. and Maibach, H.I., Eds., Patch Testing and Prick Testing, 3rd Edition, Springer, Berlin, 159-170. http://dx.doi.org/10.1007/978-3-642-25492-5_11

[5] Yagami, T. (2002) Allergies to Cross-Reactive Plant Proteins. Latex-Fruit Syndrome Is Comparable with Pollen-Food Allergy Syndrome. International Archives of Allergy and Immunology, 128, 271-279. http://dx.doi.org/10.1159/000063859

[6] Lack, G. (2008) Epidemiologic Risks for Food Allergy. Journal of Allergy and Clinical Immunology, 121, $1331-1336$. http://dx.doi.org/10.1016/j.jaci.2008.04.032 
[7] Sato, M., Shukuya, A., Sato, S., Komata, T., Utsunomiya, T., Imai, T., Tomikawa, M. and Ebisawa, M. (2016) Oral Challenge Tests for Soybean Allergies in Japan: A Summary of 142 Cases. Allergology International, 65, 68-73. http://dx.doi.org/10.1016/j.alit.2015.07.010

[8] Maibach, H.I. and Johnson, H.L. (1975) Contact Urticaria Syndrome. Contact Urticaria to Diethyltoluamide (Immediate-Type Hypersensitivity). Archives of Dermatology, 111, 726-730. http://dx.doi.org/10.1001/archderm.1975.01630180054004

[9] Lachapelle, J. and Maibach, H.I. (2012) Methodology of Open (Non-Prick) Testing, Prick Testing, and Its Variants. In: Lachapelle, J. and Maibach, H.I., Eds., Patch Testing and Prick Testing, 3rd Edition, Springer, Berlin, 147-157. http://dx.doi.org/10.1007/978-3-642-25492-5 10 